\title{
Marketing: Another Way to Establish Environmental Respect
}

\author{
HAMOU Nadia HAMOU ADNANI
}

The University of Oran, Algeria

\begin{abstract}
:
In addition to decrees and decisions of government policies forcing companies to lead a process of changing, which is part of sustainable development, promotion and encouragement can be developed based on marketing tools. The difficulty of convincing a company to implement its management with the recommendations of sustainable development practices lies in encouraging them to start a policy of changing. That is why it is consequent to push the company to rethink and put in place a new managing system.

Awareness of companies and citizens is in the centre of our communication, the state should be the first to be aware that it is nowadays essential to protect its resources, and then must introduce legislation in this way. When legal documents requiring individuals and firms to change their behaviours are absent, is not it possible to persuade firms to pursue a policy of sustainable development through the use of practices based marketing strategies (case of Non Governmental Organisations)? How should the marketing department of these companies work to transform the expenditure incurred by the changing process in a redoubtable competitive advantage (the case of businesses)?
\end{abstract}

Keywords: Marketing, Sustainable development, volunteer firms.

\section{Introduction}

It is undeniable that the most visible marketing variable for the general public has always been communication, because of its offensive sensory character that aims to be remembered. However, this important variable is only the visible part of the iceberg. Chronologically, in the context of the implementation of a marketing strategy, communication came last, well after the creation of products, setting prices and the choice of distribution channel. It is then important to understand that we need to make more or less complete overhaul of its production system in order to submit a "greener" product and sensitize consumers to choose it for this new benefit. Non Governmental Organisations (NGOs), on their part, are sensitizing companies to adopt a Sustainable Development approach, however, their tasks are not the easiest, they must have a huge and regularly updated database because their work relies heavily on communication, since they produce only information. In their role of sensitising companies, NGOs can either become groups of influence, and become specialists in arm wrestling to counter the corporate lobby that does not want to change or influence consumers to choose green products and facilitate the work of green business. The NGO's work will become in this case, strategic and can serve as a basis of argument for all members of the production /consumption circuit.

The work we will present is a bit like creating a matrix of thoughts which identifies the critical elements to consider in order to make sensitive companies to opt for a policy of sustainable development. We will, in some ways, play the role of NGOs and base our work mainly on marketing parameters and we will see the 
degree of involvement of marketing in different scenarios.

\section{Text of communication:}

In order to show how a company will be engaged or be sensitive to sustainable development, we must first explain what role marketing can have in influencing consumers and businesses through a comprehensive strategy for driving change towards a sustainable economy, we have developed two scenarios, one for a company aware of the merits of sustainable development and involvement in the change process, the second for a company that always tries to stay linked to conventional development. The creation of these two scenarios is aimed at identifying the role of marketing for each type of business. The role of marketing will, then, be as a catalyst in the first case because it is the result of internal and combined efforts (desired effects), in the second case it will have a role of brakes as it will be the result of external pressures of NGOs (sustained effects). We shall see later, a third type of companies which has emerged due to the effects suffered this type includes companies that make efforts to give the impression of following the instructions dictated by the policy of sustainable development but which is actually a minimal effort in production processes followed by a substantial effort to be noticed as a green company.

According to Demazière (2007), companies can be classified into three groups according to their degree of involvement in economic activity taking into account environmental or societal aspects/parameters:

\section{The minimalists}

These are companies whose main concern is to maximize short term profit and are not yet aware of the challenges of sustainable development. Some of their leaders support the idea that sustainable development is a fad, for them the mission of the company resides exclusively in the creation of value. The regulatory measures related to sustainable development are only constraints and brakes for the prosperity of their business.

\section{The legalistic}

Although this type of companies believes that the regulatory requirements and new processes of production of goods are very strict, they show respect to all laws, environmental as well as social.

The proactive/Volunteer

These companies are convinced of the merits of sustainable development; they are committed and are aware of the importance of environmental and social responsibility. Accelerating the speed of application of the sustainable development approach is usually caused by the personal conviction of the leaders. Such firms actively communicate on the changes they are contributor of and then create a competitive advantage. It is Monoprix case, which develops a range of products in partnership with Friends of the Earth.

Some companies have taken a good head start in thinking about how to report their social performance. Thus, Auchan and Carrefour are developing codes of social conduct; France Telecom takes specific action in matters of human resource management (such as employee involvement in the overall results), Suez implements an environmental charter and evaluates continuously the impact of its activities on the natural environment, and new functions are emerging such as sustainable development manager at Michelin in the example given in the article by Maignan and Swaen (2004).

The scenarios that we are going to present as a basis for reflection, we have devised to better define the role of marketing in the process of change towards a sustainable development policy.

\section{Scenario 1:}

We are standing before a company that decided to take the step, the company has developed a large budget to implement its sustainable development policy of its own accord. We will call these companies "Conscious Business". We mean by the word "conscious" a consciousness in relation to the effects of production on the 
environment and society and the wisdom to follow the recommendations of the various protocols with no expectation of obligations and pressures. In summary, these are companies that have decided to respect the regulations before the others.

What role for marketing in this case?

Improve or change companies production processes, it is true that it seems very restrictive because it will certainly cause enormous costs. In a pure and hard marketing perspective, it's called: developing a competitive advantage that will bring long-term results. We can already understand, at this level, that we do not have to wait until the products are marketed to contact advertisers and only focus on communication. We believe that Marketing can and should play an important role in all stages of manufacture of a product until it is consumed and beyond: research and development, production, packaging, pricing, distribution, communication and postconsumption.

\section{Research and Development:}

The report Chambolle (2006) defines ecotechnology as the set of technologies directly applied, as a preventive or curative, preservation of the environment in the classic sense (water, air, soil, waste including recovery, odors, noise ...), energy efficiency, reducing greenhouse gas emissions and using renewable energy. Marketing must be present in the research and development phase to help the company to change in the most strategic and profitable way. The variable "Product" is the Marketing Mix is the reason of being of the company, it is unimaginable that no marketing is integrated in this phase of product elaboration. The Marketing Manager will provide solutions to difficult questions, Will it be necessary, for example, to just improve the product or innovate and create a new one? Will we also have to reduce $\mathrm{CO} 2$ emissions during production through the acquisition of new processes? What improvements can we allow currently to become more efficient? What improvements will make us leader in such technology? In short, allow managers to make the best choices for long-term competitive advantage.

As an actual example, as part of his pioneer campaign "ecomagination, General Electric has set ambitious goals: reducing emissions of greenhouse gases, increase its R \& D in environmental technologies, and more, the company evaluated its campaign using scorecards to determine the strengths and weaknesses of 17 environmental key products from jet engines to solar panels, 17 products most conducive to improving environmental performance. For Esty and Winston (2008), "ecomagination is much a product strategy than effort for the environment because it focuses on specific products, including General Electric intends to sell its jet engines, and not only to receive praise from environmentalists.

\section{Production:}

Until the end of product's life, the producer retains some responsibility since it was him who made the initial choice of design, the materials used, layout, etc.. Thus, under this approach, if the producer has to bear the costs of pollution control, recycling and recovery related to the end of life of its products, it is more likely to make the right decisions to reduce those costs. In other words, it will encourage eco-designing what they will put on the market.

According to René (2009), Eco-design means all representations made in the design stage of products to reduce environmental impacts they will have during their entire life from cradle to grave " : greenhouse effect, consumption of raw materials, energy consumption, waste generated, etc.. It relies in particular on the so-called Life Cycle Assessment (LCA) not only during the phases of marketing, consumption and post-consumption, but also in a broader sense that the reference strategic aspects related to the decline phase of the product and its replacement by a new product that has a green design more elaborated. However, it remains difficult to measure the amount of ecological design of a product, because we can not aggregate its various environmental impacts in the form of a single synthetic indicator. Eco-design can also reduce the amount of 
material necessitated for an object, which will reduce all the waste afterwards. It can also play on the choice of materials (some are more easily recycled than others), their heterogeneity (in general, the more homogeneous is the product, the easier it is to treat and recycle) or on the size of the parts that make up the object (the small objects are typically more difficult to treat), etc.

\section{Packaging and post-consumption:}

If the production of goods may be polluting, its packaging can make it even more polluting, hence the need for a smart thinking to reduce post-consumption waste.

The same article by Rene (2009), many devices for financing and organizing the collection, cleanup and recovery of various types of waste are operational in France and Europe, they concern, today, batteries, motor oils, electrical and electronic equipment waste, vehicles out of use, tires, etc.. Others are under study (textiles, construction waste ...), especially in the context of the implementation of the Grenelle Environment. These devices put into practice what is called extended producer responsibility (EPR).

The EPR is based on the polluter pays principle, but considering that the polluter is not only the consumer who will get rid of the product after use, for example, the more a packaging is lightweight, the less it consumes raw materials. But if it is too small, its extraction in the mechanized sorting centers is impossible. For vehicles, the use of plastic allows relief that reduces fuel consumption during use. But plastics are more difficult to recover after mashing and more complex to recycle than steel...

Moreover, the end of life should not be the only criterion to take into account: an analysis (quoted in the article by the same author above) of the life cycle of a product has shown, for example, that the manufacture and transportation of glass containers had more impact on the environment than their end of life, whether recycled or not. Ultimately, we must make choices not to obtain the best solution, but for the best compromise.
In addition to the contributions of marketing, many functions must be involved in the packaging in firms. These include $\mathrm{R}$ \& D, packaging, procurement, logistics, production, suppliers. All links in the logistic chain are affected. Prevention is an ongoing search that only finds full effect with the involvement of business leaders and under their leadership. The environment is a dimension of corporate strategy.

What pricing policy?

Whatever the degree of its commitment, the company can not design a $100 \%$ green product, it can only strive to improve, little by little, its respect for the environment by creating greener products. The price is a very sensitive variable in the sense that each performance of cleaner production requires a significant investment in upstream which will give result, in most cases, to higher prices at least at launch of new products. The whole issue of pricing is based on the degree of engagement of consumers at launch, they must have been already sensitised to pay a little more for greener products.

Distribution: How to be successful without too much pollution?

When we talk about distribution we already mean networks and circuits, this implies, in the context of physical distribution, means of transport and logistics and as a result carbon emissions and Greenhouse Gas (GHG). To ensure a reduction of these emissions, the company must have started thinking in R \& D and production phases, hence the need for a marketing follow-up from the outset. According to the example of Esty and Winston (2008) IKEA, the legendary manufacturer of flat pack furniture has reduced the costs of its supply chain by addressing the environmental and financial costs associated with distribution of its products. The company promotes "flat packages, which maximizes the smallest space of each carton. This allows IKEA to fill its trucks and trains in a more compact way, their fill rate has increased by $50 \%$. Result: the fuel consumption has dropped 
by $15 \%$. Also, the company has been able to accommodate four more sofas per truck by reducing three centimeters from its packaging. A more extreme example, in Japan, farmers decided to grow watermelons in solid boxes; the result is impressive because, the reaped watermelons are no longer oval but cubed. This technique allows tremendous savings in terms of storage and distribution and in fact reduces the negative effects of transport on the environment.

\section{Communication:}

Once the other elements of the marketing mix have been improved in the direction of sustainable development, we will have to, at first, assess their impacts on society and environment. We had already clarified that point, the preparation of communication arguments have to begin in R \& D phase. Knowing that it is almost impossible to achieve zero error on all elements of the marketing mix, managers will need to highlight the better performance of their business. To reach a larger audience, the use of media is recommended but it is also important to publish, as frequently as possible, the result of performances related to sustainable development, using that way the company will affect all the stakeholders (clients, suppliers, shareholders) and will demonstrate the compliance of its management with actual regulations.

In our scenario, the performance will be considered as a huge effort and may even be a pioneering work which will augment the effect on public opinion and put pressure on competitors who can only be seen, at this point, as followers. On the other hand, these pioneering companies will be the first to try to convince their clients to change their behaviours, or pay a bit more for a greener product. The customer's feedback, at this level, will be unpredictable but, in the long term, their behaviours will be condemned to change in the sense of the legislation.

Highlighting the campaign demonstrates the differentiation strategy (change for better) may be a formidable weapon against competitors (this applies to the example of Monoprix, quoted in article
Tixier (2004), which explains its shares by a desire for differentiation from competitors).

\section{Scenario 2:}

We are in this second case, before a company that decided to wait until the last minute to start to change, taking advantage of its current position before being forced to make the breakthrough. We call these companies "unconscious businesses". We mean by the word "unconscious" a consciousness regarding the effects of production on the environment and society, and unconsciousness regarding to the loss of competitive advantages. In summary, these are companies that have decided to respect the rules after the others.

What role for marketing in this case?

Faced to pressures resulting from regulations, competitors and all stakeholders, the role of marketing within these companies will be a classical order and the leadership will be, sooner or later, obliged to begin to develop defensive strategies. The company's strategy in this scenario focuses on one goal: saving time (how to maintain the course of our production system longer?). In other words, the company knows that soon it can not escape the inevitable, but it continues to wait until expiration of deadlines.

Unless it is a member of a group of influence on a global scale which allows it to earn a little more time, such firm will be found very quickly under the influence of marketing actions of competitors and NGOs. It will quickly become the demon to exorcise before finally succumbing to the various offensive stakeholders.

The role of marketing in this scenario is not active but passive regarding to the competitors and NGOs actions. The company in that case must necessarily take decisions in relation with the commercial attacks and then try to repair the damages inflicted. The suffered effects may be more or less heavy depending on the power of the lobby to which the firm belongs. But the long-term leads clearly to an obscure future because it results in a loss of a 
competitive advantage and a decline in brand image among the public opinion.

However, the awareness of end customers of the merits of green consumerism has created an attraction for green products and therefore a lucrative market. Thus, companies and their marketing men have created a new concept that implies changing production processes and putting on markets shelves new products that meet the latest standard of environmental protection: "The Greenwashing". This new controversial concept and often used indiscriminately is gradually becoming a doubtful communication tool suggesting to consumers incomplete or radically false information about products.

Marketing men, under this scenario, can make use of Greenwashing to improve their company image. This concept means, according to Rixen (2008), a phenomenon which consists in giving to a company an environmentally and friendly image through advertising, a product or an event. However, the Greenwashing which seems to support a noble action is found, most often, used for a less noble one, because it is used to create a false image of the corporate and finally confuse the consumer.

We will show next, the defects introduced by some companies to pretend they have opted for a sustainable change.

In 2007, TerraChoice Environmetal Marketing conducted a study in the United States, the purpose of this study was to verify the claims of a number of products, the claims tend to promote the fact that these products are friendly to the environment. Such products play the card of ecology in their advertising or shops to attract customers concerned about the future of the earth.

After recording 1753 green claims on products in 1018, TerraChoice verified in collaboration with the International
Organization for Standardization (ISO), the Federal Trade Commission to U.S. agency, environmental protection the U.S., the 'Consumers Union and the Association of Canadian consumers. TerraChoice has finally found a list of false promises called as "Sins". Thus, one can speak of Six ways to deceive consumers. Among the products tested in 1018 only one product proved to be white as snow and has spent no falsehood in its claims.

The sin of the hidden trade-off:

This is committed when a product is called "green" based on a single environmental attribute: the recycled content of paper, for example, or a set of unreasonable attributes without attention to other major drawbacks (such as energy, global warming, water). The statements of these companies are generally true, but are used to conceal negative aspects and release a greener picture of a product, while a more complete environmental analysis would have been much more desirable. The producers of office equipment (printers, copiers, fax) which, for example, emphasize the energy savings resulting from the use of their products so they pay no attention to the harmful effects to health from some components. Many products are affected by this type of claim: Ink, detergent, deodorant, markers, pesticides, etc.. This sin is the most committed among all.

\section{The sin of No Proof:}

Any company claiming a declaration that cannot be easily supported by accessible information or by a third party certification commits the vice of No Proof. If there is no information on the compliance of the declaration, then the claim is not confirmed by lack of evidence. The lack of supporting evidence has been ranked as the second most common error according to the study of TerraChoice.

The sin of vagueness:

The allegation is said to be "unclear" if it is blurred or seems to be misunderstood by the intended consumer. 


\section{8}

Fig 1. This loop indicates that the product is made from recycled materials. But is it the whole product, or only the package? And is it made from $100 \%$ recycled materials, or less? Is it post consumer waste or post industrial waste? Without a qualifying statement, the symbol is likely to mislead the buyer, in committing the vice of vagueness.

Examples:

"Without chemicals" in fact, nothing is free from chemicals. The water is chemical, as are all of our products.

"Non-toxic" everything is toxic in sufficient doses. Water, oxygen and salt are potentially dangerous.

"Natural Product", arsenic is natural, even for uranium, mercury and formaldehyde, but all are toxic.

"Green", "green" and "eco-conscious" words are absolutely meaningless at this level.
The sin of irrelevance:

This sin is committed when the company releases positive information that is verifiable and which is of no importance for the consumer who has a preference for environmentally and friendly products and becomes consequently distracted by this product, instead of being well directed toward what he really wants. The most common example relates to chlorofluorocarbons (CFCs), a major contributor to the depletion of the ozone layer. There are no more products which are manufactured with CFCs, since they have been outlawed for nearly 30 years.

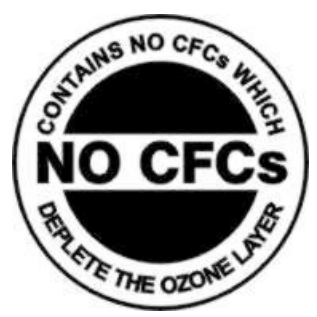

Fig 2. CFCs have been banned by law for nearly 30 years, however, many products without CFCs still claim as if it was a unique competitive advantage.

The sin of lesser of two evils:

These are "green" claims that can be verified as true in a sense, but belong to a class of products causing much controversy as being too dangerous. For example: organic cigarettes or green insecticides and herbicides. Terrachoice considers a clami to commit the sin of lesser of two evils when environmental qualifiers suah as "organic" or "green" are placed on products in which the entire product category is of questionable environmental value. "Organic" cigarettes may be a more responsible choice for smokers, but

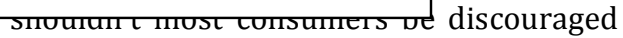
from smoking in the first place?

The sin of fibbing:

This is committed when a company makes a "Green" statement which is simply false. Examples: Many shampoos claim to be "certified organic", when no certification was confirmed. A caulking product that claims to be registered "Energy Star", while the official website of Energy Star suggests that it is false. A dishwasher detergent claims to be packaged in $100 \%$ recycled paper" while its container is plastic.

\section{Conclusion}


Throughout this article we have tried to demonstrate that Marketing has the opportunity to lend a hand to each company that recognizes the need to change their environment and take it in hand. We explained that the role of marketing should not disappear behind the communication which is only a small part of what marketing can bring. We finally turned to a new disreputable technique in order to create opportunities with consumers who are more and more caring about environment. Ideally, for a marketing manager is to support its business and allow it to be, flawless face to its consumers and, a dominating leader face to its competitors.

Green Marketing, when properly conceived and based on real evidence, accurate and relevant, becomes a major boon for an important business success. The fact that marketing is present from the phase of R \& $D$ acquires shares of green infallible communications arguments.

Marketing can already put the pressure on competitors by helping its company develop products really more environmentally and friendly in order to make consumers less sceptical and learn to differentiate between the true green product and a false one which comes from competitors. The marketing men must also build relationships of trust with their consumers, relationships based on honesty to create a perpetual dialogue and thus avoid the mistakes that can cause Greenwashing.

A perfect product and $100 \%$ ecologic does not exist, it is to create a consensus for a product that approximates the more acceptable environmentally product. Marketing must push the company to grow by encouraging innovation, but also avoiding the impertinence, concealment and fibbing and all the sins of Greenwashing. In this context, the role of marketing men is to, first, understand the environmental impact of their products throughout their life cycle and encourage progress. Then communicate the precise and relevant using plain language, without complex terms and the most honestly to avoid diverting consumers about their environmental and social concerns. It is also important at this level, to fight for certifications and communicate with supporting evidence. With all this, it will be easy for consumers to easily find what they seek; they will be the unique judge but certainly will turn to the more reassuring, the more certified and the most honest. Thus, the company will have secured a meaningful competitive advantage.

\section{References :}

Chambolle T. (2006). 'Plan d'action pour favoriser l'investissement et la création d'entreprises dans le domaine des Ecotechnologies,' Rapport au Premier Ministre, http://www.ecologie.gouv.fr

Demazière, C. (March - April 2007). 'Trois notions aux relations complexes: un tour d'horizon des controverses,' Cahiers Français, $N^{\circ} 337$, p. 84.

Esty, D. C. and Winston, A. S. (2008). 'Enterprise et développement durable',

$\begin{array}{lrrr}\text { SASCom } & \text { Second } & \text { Quarter. } & \text { [Online], } \\ \text { [Retrieved } & \text { Jun } & 20, & 2009],\end{array}$ www.sas.com/offices/europe/france/soft ware/solutions/developpement_durable/a rticle_developpement_durable.pdf

Maignan, I. and Swaen, V. (December 2004). 'La responsabilité sociale d'une organisation: intégration des perspectives marketing et managériale,' Revue Française du Marketing, $\mathrm{N}^{\circ} 200$, p. 52.

René, J. (January 2009). 'Les limites du principe pollueur-payeur,' Alternatives économiques, $\mathrm{N}^{\circ} 276$.

Rixen, J. F. (september 2008). Greenwashing. L'Art d'éco...consommer, [Online], [Retrieved Jun 2009], www.ecoconso.be/artdeco/adec40.htm

Tixier, M. (December 2004). 'Faut-il communiquer sur la responsabilité sociale? Les années 2000: un tournant dans l'entreprise,' Revue Française du Marketing, $\mathrm{N}^{\circ} 200$, p17. 


\section{Bibliography}

Boilley, E. (December 2004). 'Développement durable, transformer l'essai pour l'éco-matériaux bois', Revue Française du Marketing, $\mathrm{N}^{\circ} 200$.

Burgenmeier, B. (2008), politiques économiques du développement durable, De boeck.

Capron, M. and Quairel-Lanoizelee, F. (2004). Mythes et réalités de l'entreprise responsable, La découverte.

Chambolle T. (2006). 'Plan d'action pour favoriser l'investissement et la création d'entreprises dans le domaine des Ecotechnologies,' Rapport au Premier Ministre, http://www.ecologie.gouv.fr

Chiapello E. (1 $1^{\mathrm{er}}$ trimestre 2009). 'Les entreprises vont-elles devenir responsables?', Alternatives économiques, Hors série, $\mathrm{N}^{\circ} 79$.

Demazière, C. (March - April 2007). 'Trois notions aux relations complexes: un tour d'horizon des controverses,' Cahiers Français, $\mathrm{N}^{\circ} 337$.

Duval, G. (October 2001), 'Responsabilité sociale des entreprises, 30 groupes français testés', Alternatives économiques, Nº 196.

Duval G. (November 2002). 'Responsabilité sociale des entreprises', Alternatives économiques, $\mathrm{N}^{\circ} 208$

D'humières P. and Chauveau A. (2001). Les pionniers de l'entreprise responsables, Éditions d'organisations.

Esty D. C. and Winston A. S. (2008). 'Enterprise et développement durable', SASCom Second Quarter. [Online], [Retrieved Jun 20, 2009], www.sas.com/offices/europe/france/soft ware/solutions/developpement_durable/a rticle_developpement_durable.pdf

Lerond, M. and Lanmafankpotin, G. (2007). Le développement soutenable, Harmattan.

Lester, R. B. (2003). Éco-économie, une autre croissance est possible, écologique et durable, Nouveaux Horizons.

Lochard, J. (September 12, 2007), 'Le nouvel engouement des entreprises pour le business vert', Problèmes Économiques, $\mathrm{N}^{\circ}$ 2.930 .

Maignan, I. and Swaen, V. (December 2004). 'La responsabilité sociale d'une organisation: intégration des perspectives marketing et managériale', Revue Française du Marketing, $\mathrm{N}^{\circ} 200$.
Pautard, D. (December 2004). 'Les avantages d'une approche marketing consciente des principes de responsabilité sociétale', Revue Française du Marketing, $\mathrm{N}^{\circ} 200$.

Pinet, B. (December 2004). 'Développement durable et marketing de l'emballage', Revue Française du Marketing, $\mathrm{N}^{\circ} 200$.

René, J. (January 2009). 'Les limites du principe pollueur-payeur,' Alternatives économiques, $\mathrm{N}^{\circ} 276$.

Rixen, J. F. (September 2008). Greenwashing. L'Art d'éco...consommer, [Online], [Retrieved Jun 2009], www.ecoconso.be/artdeco/adec40.htm Tixier, M. (December 2004). 'Faut-il communiquer sur la responsabilité sociale? Les années 2000: un tournant dans l'entreprise,' Revue Française du Marketing, $\mathrm{N}^{\circ} 200$.

\section{Websites}

www.ademe.fr

www.association4D.org

www.c3ed.uvsq.fr

www.ceres.org

www.comité21.org

www.ecodurable.com

www.ecologie.gouv.fr

www.epe.asso.fr

www.orse.org

www.ecoconso.be

www.terrachoice.com 